\title{
Analysis According to the Hopkins Model of Companies' Social Responsibility Actions as Shown in Financial Statements and Social Reports - The Case of the Power Distribution Companies of the Brazilian Neoenergia Group
}

\author{
Marcelle Colares Oliveira $\ddagger$ \\ Professor in the MBA Program of Universidade de Fortaleza \\ Bruno Cals de Oliveira $\Psi$ \\ Federal University of Ceará (UFC) \\ Wilton de Medeiros Daher $\dagger$ \\ University of Fortaleza (Unifor) \\ Maisa de Sousa Ribeiro $\Theta$ \\ University of São Paulo (FEA-RP/USP)
}

\begin{abstract}
The purpose of this essay is to discuss the theoretical aspects related to adoption of corporative social responsibility practices and to verify the disclosure of social indicators, based on the Hopkins model. It seeks to answer the following questions: Which social indicators are presented in the corporate financial statements and social reports of the energy distribution companies that compose the Brazilian Neoenergia Group? What are the main actions evidenced by these companies to raise the quality and the technical standard of the services provided to consumers, since they are exclusive suppliers of this public service? It is an exploratory study, of a qualitative nature, accomplished through bibliographical, documental and multicase research. The companies under study also follow good corporative practices from the operational standpoint, offering good services with improving technical standards to their customers.
\end{abstract}

Keywords: corporative social responsibility, Hopkins Model, social indicators, brazilian power Distribution companies, multicase study.

Corresponding authors:

‡ Doutor em Controladoria e

Contabilidade

Universidade Federal do

Ceará

Endereço: Avenida da

Universidade - 2431,

Benfica, 60020180 -

Fortaleza, CE - Brasil

Email:

marcellecolares@uol.com.br

Telefone: (85) 33667802
$\Psi$ Doutor em Administração

Campus Faculdade FIA de

Administração e Negócios

Endereço: Rua do Rócio,

109, Vila Olimpia 04552-

000 - Sao Paulo, SP - Brasil

Email:

brunocalsadm@usp.br

Telefone: (11) 30915820
† Mestrado em

Administração

Universidade de Fortaleza

Endereço: Rua Barbosa de

Freitas, 200, Meirelles,

Fortaleza, CE, Brasil

Email: daher@accvia.com.br

Telefone: (85) 32649070
$\Theta$ Doutor em Controladoria

e Contabilidade

Departamento de

Contabilidade da FEA-

$\mathrm{RP} / \mathrm{USP}$

Endereço: Avenida dos

Bandeirantes $\mathrm{n}^{\circ} 3900$ Sala

14C, Monte Alegre,

14040900 - Ribeirão Preto, SP - Brasil

Email:maisorib@usp.br

Telefone: (16) 36024747 


\section{INTRODUCTION}

I

ntense competition, the change in consumers' posture from essentially passive to active in business relations and the exponential technological advance over the past half century are all factors that have been causing radical changes in productive processes and organizational relations. These changes come from a broad rethinking of production processes, as organizations recreate themselves in light of new technologies, management formats and consumer perceptions.

All companies want to achieve their goals, doing the most with the least, to ensure their long-term and profitable presence in the market.

Organizations, no matter their market segment or size, cannot survive nowadays without following the concepts of ethics, transparency and social responsibility. The survival of corporations demands implementation of policies and practices that contribute to financial success in the long-term through their relationships with all stakeholders.

To Srour (1998), corporate social responsibility must be conceived as an orientation to others, as a result of the interests at stake. Hence, there is a need to resolve complex matters, such as making profitability and respect for counterparts compatible.

Therefore, corporate social responsibility involves multiple demands imposed by modern society, involving partnership relations between customer and supplier, quality products, full satisfaction of consumers, transparent actions, contributions to development of the community, investments in technical research, preservation of the environment through non-predatory actions, profit sharing with employees, investment in staff training, respect for citizens' rights, etc.

A newly created company, beyond the objective of being lasting, profitable and solid and of enjoying a good reputation, should be aware of the prospects of the global market. International trade expands business, improves production and quality standards to meet the demands of different markets.

It is the concern of all governments and entrepreneurs to look for new opportunities, to improve business and social well-being. International businesses open the doors in this sense, since, besides increasing commercial exchange, inducing better efficiency and international competitiveness and the incorporation of new technologies and management concepts.

According to Oliveira et al. (2004), international commerce is an important spur to economic growth, and at the same time it improves access to existing improvements, through exchange with a great number of companies and contact with diversified markets, inducing restructuring and increasing corporative efficiency.

In this context, companies that intend to be recognized internationally, either for the introduction of their products or sale of their services abroad, or to attract foreign investments or loans to strengthen their base of expansion, should adopt modern management practices as a strategic competitive differential.

The present study seeks to answer the following questions: Which social indicators are presented in the corporate financial and social reports of the Brazilian energy distribution companies of the Neoenergia Group? What are the main actions evidenced by the studied companies in the sense of raising the quality and technical standard of the services provided to consumers, since the companies are the exclusive suppliers of this public service?

From these questions, thorough research was performed to test the following hypotheses: (i) if these companies adopt social responsibility practices, they are shown in their corporate financial and/or social reports; (ii) the companies adopt socially responsible actions that seek to enhance the quality and technical standard of the services provided to consumers, even though they are exclusive providers. 
This paper discusses theoretical aspects concerning the adoption of corporate social responsibility practices and tries to verify the reporting of social indicators by the energy distribution companies that make up the Neoenergia Group, which was constituted through an international partnership, and is controlled by Banco do Brasil's employee pension fund (Previ), the Spanish Hiberdrola Group and Bank of Brazil Investments.

This study is exploratory in nature, presenting and analyzing the social indicators of three of the companies composing the Neoenergia Group, with headquarters in the city of Rio de Janeiro, based on their financial and social reports for 2005.

\section{LITERATURE REVIEW}

\subsection{Main approaches to corporate social responsibility}

According to Machado Filho (2002), although the definition of a socially responsible enterprise may seem intuitively simple, there is a good deal of complexity in the conceptualization of this term. The division of social responsibility into economic, legal, ethical and philanthropic dimensions is an important reference to analyzing these variables. However, the lines between these dimensions are indistinct. Scholars of various persuasions share this perception. The consensus ends when the focus deepens on the nature of this ethical dimension. Some share the view of the stockholders, in which the managers have the exclusive duty to maximize profits and must act only in accordance with the impersonal dictates of the market, which demand efficiency and profit.

Theorists such as Adam Smith, Milton Friedman and Peter Drucker, among others, consider that the main mission of a company is to obtain the highest possible profit, as long as it functions in conformity with socially established rules. They believe that the company has no other social obligation besides providing the maximum profit to its owners.

Modern economic thinkers increasingly counter this exclusive stockholder orientation and instead argue that managers have the ethical duty to respect the rights and promote good among the agents effected by the company, including customers, suppliers, employees, shareholders, the local community, as well as management, who must be agents at the service of this wider group. In this way, these economic thinkers feel that the neoclassical view, by which the organization's social responsibility is solely to maximize stockholedrs' wealth, should have a broader theoretical approach, incorporating all stakeholders.

\subsection{The modern view of the limits of social responsibility}

According to the Business Social Responsibility Institute - the most important worldwide group in this area, whose membership in 1990 was 1600 companies, with total earnings of 1.5 trillion dollars - there is no unanimously accepted definition of the term corporate social responsibility, but in the braodest sense it refers to decisions made based on ethical values, which incorporate legal dimensions such as respect for people, the community and the environment (MACHADO FILHO, 2002).

The Instituto Ethos (2001) characterizes describes the action of socially responsible companies as follows:

Socially responsible companies have as a main characteristic ethically coherent practices and relations with their diverse publics, contributing to the continuous development of the people, communities and the relationships between themselves and the environment. When they add to their basic competencies ethical and socially responsible conduct, companies earn the respect of the people and the 
community they reach through their activities, unity of their employees and the preference of consumers.

To Lourenço and Schröder (2003), social responsibility has awakened the interests of top executives in command of organizations. The authors clarify that in 2002, an opinion survey was reported at the World Economic Forum, which took place in New York, conducted by the consultancy Pricewaterhouse Coopers, which heard 1161 corporate chief executives in Europe, Asia and the Americas, showing the growing importance of social responsibility among the corporate class:

[...] $68 \%$ agree that corporate social responsibility is vital to the profitability of them all [...] $60 \%$ of the executives believe that corporate social responsibility should assume a minor priority status in the present economic atmosphere (PASSOS, 2002, in LOURENÇO and SCHRÖDER, 2003).

\subsection{The reputation factor}

With the development of globalization, one of the determining factors for the survival of companies is development and maintenance of a favorable reputation. This perception is starting to manifest itself in in both the corporate and academic communities. Intangible assets, such as reputation, increasingly become the base for differenting firms in many sectors (MACHADO FILHO, 2002).

Zylbersztajn (2000) states that the manager who ignores the role of reputation, in a demanding and selective market, may commit irreparable mistakes, explaining that one of the most important mechanisms to control opportunism is to develop a good reputation, measured as the current value of a future resource flow derived from the value of the brand name and public image.

Offering quality products and services that meet the needs of consumers has ceased being the only differential, and is now seen more as a marketing condition. The big differential now is when the firm acts in a socially responsible way.

Corporate social responsibility is, therefore, the continuous commitment of businesses to an ethical posture that contributes to the economic, social and environmental welfare, presuming that corporate decisions have effects on the quality of life of all that gravitate around the company (ASHLEY, 2003).

\subsection{Social accounting as a way to show corporate actions}

The information offered by accountancy provides elements for analyzing organizations by their internal and external publics, who have a need to know a company's economic and financial situation.

Social advance and technological development, especially in the 1990s, combined with the growth of global competition and the increased insertion of Brazil in global markets, exposed domestic companies to outside competition, inducing them to commit themselves to management excellence.

Accountancy, initially seen as a mere instrument of registering and controlling management actions and facts, has come to be seen by firms in much wider and more useful dimension, serving as tool for strategic management of their future actions.

From this standpoint, a company nowadays must use modern accountancy, in its various aspects, such as management accounting and social accounting, beyond traditional accounting, to formulate its plan of social action (BROOKSON, 2003). 
In the social responsibility sphere, in the wider sense, a modern must use nonobligatory accounting instruments to demonstrate to interested parties its form of action vis-à-vis the market, for example: value added, cash flow and corporate social reports.

The idea of publishing corporate social reports started in France in the 1970s, and it originally only showed indicators of companies' work relationships and jobs. In the last three decades, reports on value added and environmental matters have been gradually incorporated into the disclosure (OLIVEIRA et al, 2004).

Even though in Brazil companies are not required to publish social reports and there is no required model to follow for those firms that do publish such reports, some large companies are already concerned about announcing their good corporate citizenship, as is the case of the electricity distribution companies of the Neoenergia Group, which has used the model developed by the Brazilian Institute of Social and Economical Analysis (IBASE).

\subsection{Globalized markets and the opening of new businesses}

Institutional investors in economically advanced countries, such as the United States, Spain and Japan, want to invest even more outside their domestic markets, due to the chance for better returns. Emerging countries that want to attract these investments, competing with other nations, need to adopt practices to attract and protect international investors (LODI, 2002, p.16).

Companies wishing to attract capital need to follow rules of transparent accounting, carry out their actions with management probity and account for of their actions to concerned parties. Without the necessary honesty, companies will unlikely increase their credibility and guarantee their survival. This alignment of interests is becoming compulsory. Companies adopt better management practices to assure customer loyalty, attract direct investments, foreign loans and international business.

Gradually, the globalized market is demanding uniformity and the respective reporting of the management procedures related social responsibility and good corporative governance, as key elements to the success in a very competitive market.

\subsection{Corporate Social Responsibility Indicators - The Hopkins' Model}

According to Cochran and Wood (1984), there are two ways to evaluate corporate social responsibility. One is based on indices and another is based on analysis of content, which means that one is quantitative and the other qualitative in nature. The first modality is endorsed in methods that evaluate the reputation index, based on rigorous analysis of numbers. The qualitative approach is descriptive and stops short of quantification of data. In this work, the analytical method will be used, qualititative in nature, as developed by Hopkins in 1997.

The Hopkins' indicators are divided into three levels, involving the analysis of: (i) social responsibility principles; (ii) social response capacity processes; and (iii) social responsibility results/actions. According to Queiroz (2001), indicators have a characteristic of being generic to all types companies and Hopkins proposed a way of measuring each indicator, with the ultimate objective of serving as a base for the social assessment of the company under study regarding its level of social responsibility.

According to the analytical model of Hopkins (1997, p. 581), the indicators to check the social responsibility profiles of enterprises are defined by nine elements and aim to identify the dimensions and relationships of a socially responsible company. This model uses certain information taken from the traditional annual reports and 
complementary socioeconomic and enviromental information, such as that contained in the value added and social reports.

To assess the social responsibility level of companies selected here, the Hopkins model was chosen because although it is still not that widely known, it is comprehensive in detailing the categories of analysis in relation to other existing ones.

The structure of the Hopkins analytical model is presented below.

\begin{tabular}{c|l}
\hline \multicolumn{2}{c}{ LEVEL I - PRINCIPLES OF SOCIAL RESPONSIBILITY } \\
\hline \multicolumn{1}{c}{ ELEMENT } & \multicolumn{1}{c}{ INDICATOR } \\
\hline \multicolumn{1}{c}{ Legitimacy } & \multicolumn{1}{c}{ Code of Ethics } \\
\hline \multirow{2}{*}{ Public Responsibility } & $\begin{array}{l}\text { Litigation involving the violation of laws by the company } \\
\text { Penalties due to illegal activities } \\
\text { Contribution to innovation } \\
\text { Creation of direct jobs } \\
\text { Creation of indirect jobs }\end{array}$ \\
\hline \multirow{2}{*}{ The Will of Executives } & $\begin{array}{l}\text { Code of ethics } \\
\text { Executives convicted of illegal activities }\end{array}$ \\
\hline
\end{tabular}

LEVEL II - PROCESSES OF SOCIAL RESPONSE CAPACITY

\begin{tabular}{l|l}
\hline \multicolumn{1}{c|}{ ELEMENT } & \multicolumn{1}{c}{ INDICATOR } \\
\hline Perception of the Environment & Mechanism to examine social matters relevant to the company \\
\hline Management of Stakeholders & $\begin{array}{l}\text { Analytic body for social matters as an integral part of the } \\
\text { elaboration of policies } \\
\text { Existence of a social auditing } \\
\text { Rendering of accounts concerning ethics }\end{array}$ \\
\hline Management of Matters & Policies based on the analysis of social matters \\
\hline
\end{tabular}


LEVEL III - SOCIAL RESPONSIBILITY RESULTS/ACTIONS

\begin{tabular}{|c|c|}
\hline ELEMENT & INDICATOR \\
\hline Effects on Internal Stakeholders & $\begin{array}{l}\text { Owners/Shareholders } \\
\text { Profitability/value } \\
\text { Managerial irresponsibility or illegal activities } \\
\text { Well-being of the community } \\
\text { Corporate philanthropy } \\
\text { Code of ethics } \\
\text { Executives } \\
\text { Code of ethics } \\
\text { Policies on women and minorities } \\
\text { Employees } \\
\text { Union/company relationship } \\
\text { Safety matters } \\
\text { Wages and benefits } \\
\text { Layoff/discharge policy } \\
\text { Owner employees }\end{array}$ \\
\hline Effect on External Stakeholders & $\begin{array}{l}\text { Customers/Consumers } \\
\text { Code of ethics } \\
\text { Product recalls } \\
\text { Litigation } \\
\text { Public controversies about products and services } \\
\text { False advertising } \\
\text { Environment } \\
\text { Pollution } \\
\text { Toxic waste } \\
\text { Recycling and the use of recycled products } \\
\text { Use of ecologic labels on products } \\
\text { Community } \\
\text { Corporate donations to community programs } \\
\text { Direct involvement in community programs } \\
\text { Controversies or litigation with the community } \\
\text { Suppliers } \\
\text { Corporate code of ethics } \\
\text { Supplier code of ethics } \\
\text { Litigation/Penalties } \\
\text { Public controversies } \\
\text { Organization as a social institution } \\
\text { Code of ethics } \\
\text { General litigation } \\
\text { Class actions } \\
\text { Improvement in policies and legislation due to pressures of } \\
\text { the enterprise }\end{array}$ \\
\hline
\end{tabular}

Chart 1 - Indicators on corporate social responsibility according to the Hopkins model Source: Hopkins (1997, p. 581)

\section{METHODOLOGY}

\subsection{Research typology regarding objectives, delineation and nature.}

This is an exploratory study with a qualitative nature. It is exploratory because although corporate social responsibility is a widely discussed subject nowadays, the Hopkins model is still not well explored in the literature. It is qualitative because it analyzes the phenomenon with a broad view, using description and comparison based on classification objectives that permit better reflection, unlike quantitative research that rests on numbers. 
Based on information taken from the annual corporate financial and social reports, published in printed and electronic form, of the three power distribution companies of the Neoenergia Group, we applied the Hopkins indicators model on the social responsibility of the companies.

A multicase study is an analysis of a present phenomenon, based on a real situation. Aiming at a better understanding of the phenomenon of corporate social responsibility, we chose a multicase study.

\subsection{Units of descriptive analysis}

The Guaraniana Group was constituted in February 1996 to participate in the privatization auctions under Brazil's National Privatization Program, created by Law 8031 of April 12, 1990. In July the following year, it was acquired by the Banco do Brasil employee pension fund, Previ, the Spanish group Hiberdrola Energia S.A. and Bank of Brazil Investments a subsidiary of Banco do Brasil, to become a holding company, concentrating its investments in the electric power and other utiliteis segments, focusing in the Northeast Region of Brazil.

In 2004, the holding company Guaraniana S/A was renamed Neoenergia S/A, formed of the electicity distributors COELBA (state of Bahia), CELPE (state of Pernambuco) and COSERN (state of Rio Grande do Norte), which together are responsible for $58 \%$ of the energy distributed in the Northeast and for $7 \%$ of all the energy distributed in Brazil.

\subsection{Data Treatment and Analysis}

We used content analysis, starting with the categories established in the Hopkins model, shown in Chart 1, and identified in the accounting reports and at the company sites. From the information associated to these categories, we prepared a descriptive content analysis, shown in Chart 2, indicating with YES or NO the existence or absence of these indicators according to the reports and sites.

\section{ANALYSIS OF THE SOCIAL RESPONSIBILITY INDICATORS OF COELBA, CELPE AND COSERN}

These companies, besides the reports required by law, issue the following nonmandatory statements: value added, cash rlow and social report.

Below we present our findings about the companies' social responsibility indicators, according to the Hopkins model.

\section{Level I - Principles of social responsibility}

\section{Legitimacy}

The three companies have ethics codes. COELBA and COSERN have ethics committees, which meet periodically to ensure the codes are followed. Additionally, the codes are easily accessible on the Internet. CELPE realized actions with the intention to spread this code, through the performance of the Committee of Ethics, the insertion of the ethical subject in the events promoted by the company and the use tools to control the index adhesion, internalization and the code break.

\section{Public responsibility}


The records of possible litigation involving the violation of the laws by the three companies are presented in the notes to the annual reports. In the specific case of the Companies of the Neoenergia Group, they make specific provisions to validate lawsuits in the labor area, involving payment of overtime, hazardous working conditions and wager matching; in the civil area, regarding the Plano Cruzado of $1986^{1}$ and; in fiscal area, concerning INSS, COFINS and PIS $^{2}$.

Concerning the contribution to innovations, it can be observed that COSERN, COELBA and CELPE invested in the improvement and maintenance of their operating quality standards and capacity to supply electricity to their customers. COELBA was the only one that divulged the total invested in researches and development. Concerning the investments in professional training, all three companies made significant investments.

Relative to the number of employees, COELBA and COSERN increased their staffing and CELPE reduced its. The debate which surrounds this subject refers mainly outcontracting of unqualified people in companies in this segment. Furthermore, mere job creation does not necessarily promote generate wealth and promote social well-being. In the companies in this study, this situation has bearing because there has not been a rise in the total number of employees, and there has been significant outsourcing.

\section{The Will of the Executives}

No information was found about the existing code of ethics and possible deviations of conduct by the executives.

\section{Level II - Processes of social response capacity}

In this part there are two relevant indicators related to the perception of the environment and to the management of stakeholders. Concerning the first one, this mechanism of analysis seeks to understand social matters relevant to the company such as the management indicator of the stakeholders seeks to check the actions themselves as an integrating part of the elaboration of social policies. Of the three companies, only CELPE invested significantly in the environmental area, while COELBA and COSERN expended less money.

On the other hand, COELBA spent more on the external social area (education, culture, health and sewerage, donations, sports program sponsorship, efforts to fight hunger and promote food safety, etc.), while CELPE, COSERN invested less than the others.

\section{Level III - Social responsibility results/actions}

\section{Effects on internal stakeholders}

\section{Owners/shareholders}

The effect on the owners/shareholders and executives of the companies' social actions results for damages under the angles focused in the model (profitability/values, administrative irresponsibility or illegal activities, well-being of the community, corporative philantropy, code of ethics) are vacant evidenced.

The information concerning profitability and the value of the companies is easily identified in their financial reports. As for the information on the philanthropic actions directed towards education, culture, sports, and health, each distributor has spent sums to

\footnotetext{
${ }^{1}$ An ultimately unsuccessful economic stabilization plan by the government which, among other privisions, froze prices, leading to many lawsuits on the appropriateness of the currency converstion rates and inclusion of past inflation in rate adjustments.

${ }_{2}$ Social Security Contribution, Contribution to Finance Social Security and Contribution to the Social
} Integration Program, respectively, all of them federal levies

BBR, Braz. Bus. Rev. (Eng. ed., Online),

Vitória, v. 3, n. 1, Art. 3, p. 32-44, jan.-jun. 2006

www.bbronline.com. br 
have frontage to be showed as one of the sponsorships of these programs on the sponsorship of these programs. However, there is no mention in relation to owners/shareholders and executives.

\section{Employees}

The three companies demonstrate concern while exercising organizational citizenship. Many actions seeking the well-being of their employees are taken, shared with the workers, for example, discussion of occupational health and safety issues. COLBA has 1,525 employees over 45 years old. COSERN has 27 physically deficient workers on staff. And CELPE, for example, got an $89 \%$ approval rating from a survey on its organizacional climate carried out in 2005. In the three companies, all the employees have the right to a private retirement plan and profit sharing program.

Other information of the Hopkins model, like the effect on the employees of the unioncompany relations, pay and benefits, severance plans and policies on women and minorities are not necessarily detailed, but are instead found vaguely in the IBASE Social Report published by the three companies.

\section{Effect on external stakeholders \\ Customers/Consumers}

Two important indices show the degree of satisfaction of electricity consumers: the Interruption Duration per Consumer (DEC) and the Interruption Frequency Index (FEC). The companies have invested significantly to improve the quality of their operational services. In 2005 , they invested in programs for service quality improvements. As a result, the distributors of the Neoenergia Group obtained a reduction of the DEC and FEC indices. This evolution is even more significant if compared to the year of privatization (1997 for COELBA and COSERN and 2000 for CELPE).

With the objective of offering greater comfort to consumers, the three companies customer response programs, be it by call center (toll free), Internet (Online Agency) or by self-service machines, besides keeping offices in the main neighborhoods.

Specific information about product recalls, litigation, public controversies about products and services and deceptive advertising are not set given at the companies' sites and in the reports.

\section{Environment}

The companies all have environmental preservation programs, such as the publication of environmental folders for distribution in poor communities, implementation of recycling programs with collection of trash for recycling, efficient energy awareness, programs to collect left-over transmission materials (wires , copper handles and aluminum), aiming at cleanness and reuse of these materials, regular participation on committees, community meetings, commemorative meetings with the Public Administrationand meeting on awareness of enviromental questions.

From that reported by the companies themselves, there is no information on pollution or toxic waste or ecological labeling on products, all factors of the Hopkins model.

\section{Community}

The companies have direct involvement with the communities where they act, through specific projects, such as: house of diligent minor; development of cooperatives; culture and sports programs through sponsorships; educational programs on rational energy consumption; 
digital inclusion programs; social actions in partnership with charitable entities, such as the Institute for the Blind and Cancer Institute, extended daycare centers, public elementary schools, etc. The companies also organize and stimulate their employees to participate in volunteer programs.

The companies do not mention controversies or litigation with the community.

\section{Suppliers}

There is no specific information on the commercial relationships with suppliers, except informative programs directed to construction managers and service providers, concerning aspects related to tax planning, codes of ethics and environmental preservation. Suppliers are required to follow the same ethical, social and environmental responsibility programs adopted by the companies.

The companies do not mention the effect of the codes of ethics on suppliers, or litigation/penalties and public controversies involving suppliers.

External institutional effects

The companies have a good deal of political influence over the communities and regions where they operate, which is used as an instrument to intervene in several spheres of power. The direct contact with governmental groups expects, on the one hand, a high level of responsibility in the technical and institutional fields and, an on the other, strong involvement with programs of collective interest, some of them inspired by their own state or local governments. Besides being large taxpayers, the distributors of the Neoenergia Group maintain ongoing social support programs.

The companies do not do mention external institutional effects of their codes of ethics, general litigation, class actions or improvements in polities and legislation as a result of company pressures, elements contained in the Hopkins model.

\subsection{Final considerations on the applicability of the Hopkins model.}

The intention of the Hopkins (1997) work is to permit individual analysis of companies, as well as of nonprofit and non-governamental organizations. The model's premise is to measure the involvement with socially responsible actions as a normal practice within enterprises, with the understanding that their objetive in society includes the exercise of responsibility in the economic, ethical, political and philanthropic dimensions (QUEIROZ, 2001).

The companies studied in general met the attained the indicator of levels I and II as far as their social reports, annual reports or sites. However, there is no detailed information regarding codes of ethics. In relation to information about diverse litigation (labor and tax area), it is very general, limited to reporting amounts of provisions for contingencies for actions in course. There was no evidence of the existence of social auditing in any of the companies, nor is there a specific report on compliance with ethical standards.

Relative to level III of the model, referring the Social Responsibility Results/Actions, some of the constant elements of the indicators are evidenced in the financial reports, as shown in the previous topic. Many elements located in the model did not fit or were not shown. In relation to Level III, most of the information identified dealt with positive aspects and did not influence the negative aspects contained in the model, such as legal actions.

It can be perceived that the model is sufficiently pertinent to the analysis of the social actions and that each company must make some adaptations in view of its brach of activity; as well as reflections they must be made in the and the companies do not have, effectively, to provoke negative effect in its stakeholders but that, in occurring, they must evidence them, as foreseen in the Hopkins model. 
Chart 2 below summarizes the social action analysis of COELBA, CELPE and COSERN, according to the indicators of the Hopkins model.

\begin{tabular}{|c|c|c|c|c|}
\hline \multicolumn{5}{|c|}{ Level I - Principles of Social Responsibility } \\
\hline Element & Indicator & COELBA & CELPE & COSERN \\
\hline - Legitimacy & - Code of ethics & YES & YES & YES \\
\hline $\begin{array}{l}\text { - Public } \\
\text { Responsibility }\end{array}$ & $\begin{array}{ll}\text { - } & \text { Litigation involving the violation of } \\
& \text { laws by the company } \\
\text { - } & \text { Penalties due to illegal activities } \\
\text { - } & \text { Contribuition to innovations } \\
\text { - } & \text { Creation of direct jobs } \\
\text { - } & \text { Creation of indirect jobs }\end{array}$ & $\begin{array}{l}\text { YES } \\
\text { NO } \\
\text { YES } \\
\text { YES } \\
\text { NO }\end{array}$ & $\begin{array}{l}\text { YES } \\
\text { NO } \\
\text { YES } \\
\text { YES } \\
\text { NO }\end{array}$ & $\begin{array}{l}\text { YES } \\
\text { NO } \\
\text { YES } \\
\text { YES } \\
\text { NO }\end{array}$ \\
\hline $\begin{array}{l}\text { The Will of } \\
\text { Executives }\end{array}$ & $\begin{array}{l}\text { - } \text { Code of ethics } \\
\text { - Executives convicted of illegal } \\
\text { activities }\end{array}$ & $\begin{array}{l}\text { YES } \\
\text { NO }\end{array}$ & $\begin{array}{l}\text { YES } \\
\text { NO }\end{array}$ & $\begin{array}{l}\text { YES } \\
\text { NO }\end{array}$ \\
\hline \multicolumn{5}{|c|}{ Level II - Process of Social Response Capacity } \\
\hline Element & Indicator & COELBA & CELPE & COSERN \\
\hline $\begin{array}{ll}\text { Perception } \\
\text { Enviroment }\end{array}$ & $\begin{array}{l}\text { Mechanism to examine social matters } \\
\text { relevant to the company }\end{array}$ & YES & YES & YES \\
\hline $\begin{array}{l}\text { - Management } \\
\text { Stakeholders }\end{array}$ & $\begin{array}{l}\text { - Analytic body for social matters as } \\
\text { integral part to the elaboration of } \\
\text { policies } \\
\text { - Existence of social auditing } \\
\text { - Rendering of accounts concerning } \\
\text { ethics }\end{array}$ & $\begin{array}{l}\text { YES } \\
\text { NO } \\
\text { NO }\end{array}$ & $\begin{array}{l}\text { YES } \\
\text { NO } \\
\text { NO }\end{array}$ & $\begin{array}{l}\text { YES } \\
\text { NO } \\
\text { NO }\end{array}$ \\
\hline $\begin{array}{ll}\text { Management of } \\
\text { Matters }\end{array}$ & $\begin{array}{l}\text { Policies based on the analysis of social } \\
\text { matters }\end{array}$ & YES & YES & YES \\
\hline
\end{tabular}

\begin{tabular}{|c|c|c|c|c|}
\hline \multicolumn{5}{|c|}{ Level III - Social Responsibility Results/Actions } \\
\hline Element & Indicator & COELBA & CELPE & COSERN \\
\hline $\begin{array}{l}\text { Effect on Internal } \\
\text { Stakeholders }\end{array}$ & $\begin{array}{l}\text { - Owners/Shareholders } \\
\text { - Executives } \\
\text { - Employees }\end{array}$ & $\begin{array}{l}\text { NO } \\
\text { NO } \\
\text { YES }\end{array}$ & $\begin{array}{l}\text { NO } \\
\text { NO } \\
\text { YES }\end{array}$ & $\begin{array}{l}\text { NO } \\
\text { NO } \\
\text { YES }\end{array}$ \\
\hline $\begin{array}{l}\text { Effect on external } \\
\text { Stakeholders }\end{array}$ & $\begin{array}{ll}\text { - } & \text { Customers/Consumers } \\
\text { - } & \text { Enviroment } \\
\text { - } & \text { Community } \\
\text { - } & \text { Suppliers }\end{array}$ & $\begin{array}{l}\text { YES } \\
\text { YES } \\
\text { YES } \\
\text { YES }\end{array}$ & $\begin{array}{l}\text { YES } \\
\text { YES } \\
\text { YES } \\
\text { YES }\end{array}$ & $\begin{array}{l}\text { YES } \\
\text { YES } \\
\text { YES } \\
\text { YES }\end{array}$ \\
\hline $\begin{array}{l}\text { - Effect on external } \\
\text { Institutions }\end{array}$ & - Organization as a Social Institute & YES & YES & YES \\
\hline
\end{tabular}

Chart 2 - Summary of analysis of corporate social responsability actions of COELBA, CELPE and COSERN, according to the indicators of the Hopkins model. Source: Prepared by the authors from Hopkins (1997).

\section{CONCLUSION}

The analytical models of corporate social responsibility practices, such as the Hopkins model, are important instruments to analyze the level of involvement of companies in the face of growing public demand for good corporate citizenship.

In the specific case study examined the corportate social responsibility practices of the electricity distribution companies of the Neoenergia Group, not only from a philanthropic angle, but also from the operational point of view, seeking to offer good services to consumers with improving technical standards. The awards the three companies have 
received in this respect are strong indications that qualify them as socially responsible companies. COELBA, CELPE and COSERN, through advanced practices of reporting social indicators, rendering accounts to their business society and their actions, confirming the assumptions collected to this paper.

\section{REFERENCES}

ASHLEY, Patrícia Almeida (Coord.). Ética e responsabilidade social nos negócios. São Paulo: Saraiva, 2003.

BROOKSON, Stephen. Como entender a Contabilidade. Translation Anna Quirino. São Paulo: Publifolha, 2003.

COCHRAN, Philip L.; WOOD, Robert A. Corporate social responsibility and financial performance. Academy of Management Journal, 1984, vol. 27, no. 1, pp. 42-56.

HOPKINS, Michael. Defining indicators to assess socially responsible enterprises. Kidlington: Futures, 1997.

INSTITUTO ETHOS. Guia de elaboração de relatório e balanço anual de responsabilidade social empresarial. São Paulo: Instituto Ethos, 2001.

LODI, João Bosco.Governança corporativa: O governo da empresa e o Conselho de Administração. Rio de Janeiro: Campus, 2002.

LOURENÇO, Alex Guimarães; SCHRÖDER, Débora de Souza. Vale investir em responsabilidade empresarial? Stakeholders, ganhos e perda In: Responsabilidade Social das Empresas - a contribuição das universidades. São Paulo: Peirópolis, 2003.

MACHADO FILHO, Cláudio Antonio Pinheiro. Responsabilidade social corporativa e a criação de valor para as organizações: um estudo multicasos. Doctoral thesis. School of Economics, Administration and Accounting of University of São Paulo/USP, 2002.

OLIVEIRA, Marcelle Colares et al. Responsabilidade social corporativa e negócios internacionais: um estudo das empresas baianas.In: XVII CONGRESSO DA SOCIEDAD LATINOAMERICANA DE ESTRATÉGIA - SLADE, 2004, Itapema, Santa Catarina, Brazil. Anais... Santa Catarina: SLADE, 2004.

QUEIROZ, Adele. A utilização de indicadores de responsabilidade social das empresas. MBA dissertation. São Paulo: Fundação Getúlio Vargas, School of Business Administration, 2001.

SROUR, Robert Henry. Poder, cultura e ética nas organizações. Rio de Janeiro: Campus, 1998.

ZYLBERSZTAJN, Decio. A organização ética: um ensaio sobre as relações entre ambiente econômico e o comportamento das organizações. Working Paper. Text based on erudition class to obtain full professorship. São Paulo. School of Economics, Administration and Accounting, Universty of São Paulo/USP, 2000. 